\title{
The Reality behind the Rhetoric: an Examination of Saudi Vision 2030 Using Imminent Critique
}

\author{
Muhammad Fauzi Abdul Rachman \\ Universitas Pertamina \\ Email:mfarachman@gmail.com
}

\begin{abstract}
The Saudi Vision 2030 is a Saudi statement of intent to transform the economic structure of Saudi Arabia from oil-based exports to a more skill-based economy. This paper conducted a critical review of the statement, comparing the stated intent of the Saudi authorities with the political situation in the country and region. It was found that given the present power structure, which the government has no intention of changing, the vision is unlikely to be successfully implemented. One of the strongest points in this Vision concerns human development of skills needed in the new order. However, the overt of human right violations within the regime would make realizing the full potentials of its citizens difficult. In particular, the misogynistic policy of denying half its population equal rights would neglect the potential of half of its people. Furthermore, the policies of the state directly contravene the rights and freedoms of people and of other countries in the region as proclaimed in the Vision. This state, then, would be extremely unlikely to fulfil its Vision unless it begins to recognise the basic human rights of all of its citizens. In other words, the Saudi regime would need to adopt less dogmatic policies for the Vision to have any chances of succeeding.
\end{abstract}

Keywords: Human Development; Economic Transformation; Oil Politics

\section{Introduction}

Saudi Arabia proclaimed the Saudi Vision 2030 in April 2016 in preparation for a post-oil economic.
It is centre of their grand strategy to reform their economy, since the monarchy state can no longer provide everything for its citizen 
by oil exports alone, and the full utilisation of its people's potential is the main strategy for the future prosperity of the kingdom (Young, 2016). A vibrant society is one of the three themes that underpins the vision. They understand that their people will be their strongest asset to achieve the Vision's target. The Vision states: "We have enormous untapped opportunities and a rich blend of natural resources, but our real wealth lies in our people and our society." Therefore, there is a strong need for a good relationship between the kingdom and its citizens if the ambitious project is to succeed. As John Edwards, a member of the board of the Reserve Bank of Australia, said, the success of the Vision requires profound changes in Saudi society and politics (Khashan, 2017). This article will critically assess the Saudi Vision 2030 in several areas which may affect its successful implementation. These are: Human rights violations including women rights, lack of press freedom, no freedom of assembly, intervention to Yemen government and diplomatic crisis with Qatar. The Saudi government talks of about ambition, tradition, religion, kingdom, technology, modernity, development, investment, job opportunities, but they neglect humanity, which seems to go against the central tenets of the Vision.

\section{Literature Review}

\section{Vision 2030}

The Gulf Cooperation Council Countries Bahrain, Kuwait, Oman and the United Arab Emirates have the similar concept of their economic visions (Mitchell, 2018). However, the Kingdom of Saudi Arabia's Vision steals the world attention since they are the largest regional economy and one of the most influential countries in the Middle East. KSA launched Vision 2030 based on three pillars and three themes. The three pillars are becoming the heart of Arab and Islamic worlds, the investment powerhouse and the hub connecting three continents, whilst the themes cover a vibrant society, a thriving economy and an ambitious nation (Kingdom of Saudi Arabia, 2016b, p. 13). The Vision gives the direction of Saudi's economy for the future but is not offer a sense of political vision. However, it is very unclear what kind of political change would emerge in Saudi that follows the vision (Kinninmont, 2017). Bernard Haykel named it "revolution from above" (Gause, 2018) without strengthening on the "below" that is 
facing tensions in the House of Saud and unstable regional situation.

\section{Women Rights}

Merlyna Lim wrote that Western views on feminism are adverse to Saudi Arabia's local knowledge (Lim, 2018) while Acker (2009) posits the concept "inequality regimes". Acker claims that the idea can capture complex, interlocking practices and processes that result in continuing inequalities in all work organisations, including top management levels. The processes of inequality shape work organisations and the experiences of employees at every level, leaving women in lower positions within the hierarchy (Acker, 2009; Abalkhail, 2017). Studies have found that within Arab countries, institutional forces are responsible for the limited progression of women to leadership positions, which is rare in patriarchal societies (Abalkhail, 2017). In Saudi Arabia, however, women have less access to organisational resources, for instances, information, participation in strategic planning and financial decision making (Abalkhail, 2016). Furthermore, vertical segregation, where women's roles simply support man is familiar. The dominant religion in Saudi Arabia is Islam, which has played a significant role in defining and shaping its culture. The ideas of qiwama, which is mentioned in the Qur'an (4:34), for example, is widely interpreted by religious scholars as meaning that God created men superior to women (Mernissi, 2011. Abalkhail, 2017). According to Mernissi, (2011) and Abalkhail (2017), however, that is a misinterpretation of Islam based on patriarchy.

This misinterpretation has resulted in Saudi females being culturally socialised to adopt certain attitudes, such as the importance of caring for their husbands and their families (Tlaiss and Kauser, 2011. Abalkhail 2017). Even though there were development plans to reduce gender inequality, including in the education system, women's participation in the labour market remains very low (Abalkhail, 2017). Gave the right to drive, does not mean lifting the ban for some figures that fight for the privilege. Loujain al-Hathloul, an important figure who fought for the driving reforms, is still in jail. Furthermore, women freedom to choose many basic decisions is still blocked by strict guardianship laws (The New York Times, 2019). Reema bint Bandar bin Sultan bin Abdulaziz Al Saud is the first female ambassador who has 
been appointed by the kingdom as an ambassador to the U.S., but she is a royal family member. Saudi labour laws, although espousing the need for equal treatment, discriminates against women (Abalkhail and Allan, 2015). Such laws assume males are the primary income providers, whereas women work either to subsidize family income or for self-satisfaction (Abalkhail, 2017). Abalkhail asserts that Vision for 2030 can be a promising path for greater equality, and the Saudi Government's also made some efforts to achieve United Nations' MDG, but it needs collaboration between the government, organisations and individuals if this to be realised.

Next, heightened uncertainties over an unexpected event (terrorist attacks, Brexit, Trump's win in the 2016 US presidential elections) (Bouoiyour, 2018) have prompted a decline in investment (Branden and Yook, 2012. Boe and Jordal, 2016). Furthermore, the gruesome killing of a journalist and the arrest of women activists have hindered the progress of the Vision. It was proved when many big companies take back their willingness to invest on the Kingdom, including the suspension from Sir Richard Branson related to his investment to Saudi and condemnation by Dara Khosrowshahi, Uber CEO who also cancelled his attendance to FII conference in Riyadh, because of the Jamal Khashoggi'case.

\section{Regional Issue}

Around $9.5 \%$ of the world's total size is covered by the $22 \mathrm{Arab}$ countries and they have a population of about $4 \%$ of the whole world. The Arab world has become more important since they own abundant oil and gas resources and strategic position in geopolitics (Yao, 2007). The Middle East has nonstop chaos related to regional instabilities, global order, and political-economic order. Religious reformists versus religious extremists, Sunni versus Shia, and other differences of beliefs are playing a big role (or has been only used as a rumour) on the regional instabilities. In terms of global order, the Middle East is a battlefield for big power countries such as the U.S., Russia, and other European countries. The rising of China as a new big power also make the problem more complicated at the struggling of influence and economy in this region. Besides, the relation of the U.S.-Israel in the region exacerbates the chaos, particularly on the land seizure to Palestinian territories. It made a 
huge disadvantageous influence on the Arab world and held back the pace of their reform and development (Yao, 2007).

For Instance on Saudi's case, Alshabnan declared on his paper that the Saudi Foreign Ministry stated that Qatar is "harbouring terrorist and sectarian groups that threaten regional stability, including the Muslim Brotherhood, ISIS and Al-Qaeda, and promoting their literature and plans consistently through its media outlets." In contrast, Al-Jazeera reported, supported by the Iranian Foreign Ministry, that Saudi is the lead supporter of extremist ideology and terrorism (Alshabnan, 2018).

A prove that shown regional disharmony can create a bad effect on the economy in the Middle East can be found when the Yom Kippur War by a coalition of Arab states led by Syria and Egypt against Israel and the Islamic Revolution in Iran made an economic downtrend in the region (Klare, 2017). It was a disharmonic situation that the U.S. and European government need, which lead them to control oil resources in the Middle East and to keep their influence at the area, as Israel's strategic relationship with the U.S. has been stronger since then (Kumaraswamy, 2007).

\section{Methodology}

A document analysis and qualitative research method was held in order to fulfil the objective of this paper. The Saudi Vision 2030 and National Transformation Program 2020 were analysed, interpreted and used as the main resource to collect the data and to do the critical review. Numerous pieces of previous academic research related to the Vision were utilised to sharpen the criticism and to wrap up the literature review. The Research was conducted between December 2018 and February 2019. The research is limited to the Vision's rhetoric, which also means this focal point is in circa 2016 and afterward. During the processing, time limitedness was the main problem, as some deadlines appeared in short notice.Through the methodology mentioned above, the paper's aim is to explore one main notion: The Kingdom would be extremely unlikely to fulfil its Vision unless it begins to recognise the basic human rights of all of its citizens and respect the sovereignty of other countries in the region to ensure a peaceful environment conducive to economic development. 


\section{Results}

MBS

Around a year after the launching of the Vision 2030, Prince Mohammed bin Salman bin AbdelAziz Al Saud (often referred to as 'MBS') was named by his father King Salman as Saudi Arabia's new crown prince. MBS is known as the key person behind Vision 2030 (Kinninmont, 2017). Nevertheless, the appointment of MBS was labelled as Saudi's Arab Spring by New York Times in 2017 (Bouoiyour, 2018). MBS is suspected by US intelligence agencies as the mastermind behind the killing of journalist Jamal Khashoggi. Furthermore, it has been widely speculated that he is the chief protagonist in the military intervention in Yemen since 2016, the Qatar diplomatic crisis in June 2017, the arrest of his rivals in November 2017, and the detention of the Lebanese Prime Minister Saad Hariri in December 2017 (Bouoiyour, 2018). For now, MBS can do anything that is considered will lead to his goal because he is backed by his father, King Salman, age 83. Including to clear any obstacles that can ruin his power. It is proven on the arrest of some family members of the royal family as well as wealthy businessmen and ministers. The problem will occur if King Salman dies, the princes who are in the opposite position to MBS could fight back his reign. It is clear that one of the world's richest men, Prince Alwaleed bin Talal is against MBS. The domestic dispute, moreover inside the royal family, can interrupt the Vision goal that really needs political stability. Saudi has a long record about the story of friction within the Kingdom, one of the most prominent events was the assassination of King Faisal in 1975.

Not only a concordance inside the kingdom and the nation but also Saudi foreign policy should be set as a support system to aim the Vision's main purpose. On the contrary, MBS put some pressure on the Lebanese political system during his early dominion and intervene in the domestic politics of their neighbours (Gause, 2018).

\section{Regional relations}

Saudi GDP is the highest in the Middle East, with a value of SAR 2.4 trillion (Vision, 2016). It needs constructive relations with Islamic and foreign countries, particularly within its region. Goods, people and capital should have a smooth flow by air, maritime and other transport operators to strengthen businessfriendly environment. Saudi is also a member of The Gulf Cooperation 
Council (GCC) that focuses on political and economic aspects between six countries, including Qatar, and they are considering giving membership to Yemen.

However, Saudi and Qatar have been in a diplomatic war since June 2017. Saudi led a coalition of Arab countries that claimed Qatar was supporting terrorism in several countries, including Saudi Arabia, Egypt, Bahrain and the United Arab Emirates. Based on those accusations, it has closed the land, sea and air borders with Qatar. This conflict is very contradictory with the rhetoric contained within the Vision.

Besides Qatar, Saudi is also having a trouble with another bordering country to the south, Yemen. Saudi military intervention has been launched towards Yemen sovereignty since 2015. One of the most Saudi killing actions in there was a bombing on a school bus packed with children in 2018 . Children, with most between the ages of six and eleven, were killed. Two weeks after, other Saudi-led coalition airstrike killed other 26 children and four women in the western province of Hudaydah (Guardian, 2018). Furthermore, a CNN's report states that Saudi Arabia and UAE transferred US- made weapons to al-Qaeda-linked groups and a Salafi militia, who worked with ISIL, in Yemen (AlJazeera, 2019).

\section{Freedom of assembly}

Karen E. Young stated that one of Saudi main problems is that the state has not created an institutional framework that allows citizens (not to mention foreign laborers and foreign investors) to create new organisations. The Kingdom wants to keep tight control of every organisation which is formed inside their territory. The abuse of power by the Saudi authorities in keeping its citizens on a tight leash could damage the future prospects of the Kingdom.

If the Saudi regime were to relax its tight grip and allow its citizens more freedom to express their creativity, it would help the human development which is the stated aim of the Vision. People need freedom to fully realise their potential, and the current restrictive Saudi regime is not conducive to this. For any economy to fully prosper, there need to be creative space for people to think and act freely, within reason. People must be free from the fear of transgressing undue restrictions from the Kingdom's unjust laws. 
The logical result of freedom of assembly are public demonstrations, which are not permitted in the kingdom under any circumstances. The former interior minister Prince Nayef bin Abd al-Aziz said that demonstrations were "not compatible" with the kingdom's social system (Human Rights Watch, 2002). Of course, what he means is that demonstrations are not in the interest of his authoritarian ruling order. It always begs the question when regimes without a popular mandate declare this or that is not compatible with a certain social system or not in the people's interest, on what basis are they qualify to make such statement? In fact, even in the absence of universal suffrage, peaceful demonstrations could be useful controls to prevent abuses of power and act as a safety valve before discontent turns into something more serious.

However, reforms is not likely to happen, as the kingdom has a long tradition of authoritarian rule, and keep a tight control over their own people. The raise of nongovernmental organisations and people power may well weaken the regime. However, without the freedom of association, the Vision could never be realised maximally.
The regime may be afraid to relax their control by giving people such basic freedom as freedom of assembly will likely be followed by demands other freedom and better awareness towards other rights.

\section{Women Rights}

"We are determined to build a thriving country in which all citizens can fulfil their dreams, hopes and ambitions.", or so it is boldly proclaimed the foreword of Saudi Vision 2030. However, women are marginalised by long traditions of misogyny in Saudi Arabia. For gender parity, Saudi Arabia has been ranked 141 out of 144 countries by The World Economic Forum's 2016 Global Gender Gap Report (Baqi, et. al, 2017). Patriarchy culture has been, and still are, rooted in Saudi daily life. Therefore, there is a need to change the culture if the Saudi regime is serious about the Vision, rather than making rhetorical noises. Misunderstanding of social tradition, Islamic teaching and culture are the main hindrance for women to participate in the workforce (Arabi, 2018).

The Vision mentions the strong foundation of a vibrant society is based on the family, which means family harmony should to give a stronger foundation for a better 
society. However, in Saudi, a father is interpreted as the head of the family based on Islam, and this gender inequality runs through every level of society. The proclaimed Vision would appear that the kingdom is focusing on the future of the children in families, and that the engagement of parents in their children's future is the key. Parents, however, are more than the father making all the major decisions. It must also include the wife if human potentials are to be utilized to the maximum.

Gender inequality case can also be found in the education system. The second theme of Vision 2030 is "a thriving economy provides opportunities for all by building an education system aligned with market needs..." In reality, even though 58 percent of all university graduates are women, their educational background cannot guarantee an access to the labour markets (Baki, 2004). Since women can only choose particular field during their study, such as dentistry, education, medicine, nursing, and public administration, they are excluded from studying engineering, journalism, pharmacy, and architecture. The facts, then, do not coincide with the Vision.

Saudi will lose the potential of half of its people if gender inequality is tackled seriously. The World Bank data in 2017 showed that $42.93 \%$ of Saudi Arabia population are female. However, females make up takes $16 \%$ of total Saudi's labour force in 2018. However, the Vision states that there $22 \%$ of women participate in the workforce and they want to increase this to $30 \%$.

Many "new" rights are given to Saudi women to support the Vision, such as women can vote and get elected, is allowed to become notary publics, to be the head of the stock exchange and to attend into sports stadiums and music concert. One of the most significant decisions for Saudi women was the lifting of the ban on women driving, a mass protests to this issue started in June 2011 (Lim, 2019), which lead to over 120,000 women applied for driver's licenses. It will bring massive change for Saudi social life. It boosts the work force, as women can become more productive and men will have more spare time to do something else instead of driving. Unfortunately, this policy brings also counteraction from some clerics who are regarded as "not ready" or "too conservative" religious (Gause, 2018).

\section{Islam as Saudi's Main Pillar}

Human Capital Development in Saudi Arabia will become an 
unavoidable conflict between reformists and religious conservatives (Yamada, 2018). Economic reforms are associated with Westernisation while most historical political opposition for the Kingdom claimed themselves as representatives of authentic Islamic values (Kinninmont, 2017). Religious studies take $29.3 \%$ of the total curriculum in Saudi in the primary school level, the highest portion among other subjects (Yamada, 2018). The religious studies tend to a piece of knowledge about Islam's dogma, but the Vision 2030 needs more than that, skills, creativity, analytical and critical thinking.

Saudi always bring Islam into almost every single context related to them, including this Vision. Islam's doctrine, surely, is not teaching Muslims to kill and to silence people voice and to hinder Muslims to do the pilgrimage. Islam teaches Muslim to respect all human dignity and rights, including honesty, not only as an icon for branding.

On the blueprint, Mohammad bin Salman bin Abdulaziz Al-Saud wrote their status as the land that was given the Two Holy Mosques by Allah the Almighty as their first pillars (Kingdom of Saudi Arabia, 2016). This rhetoric contains problem which is that Allah the Almighty would not give sacred sites to a single nation. Muslims are all over the world, and their prayer direction cannot be monopolised by a single nation. Furthermore, Saudi Arabia uses Islam and Islamic holy sites for business or political bargaining position. When a belief is being monetized by a kingdom or a nation, the sacred itself can be questioned. Indeed, in the foreword of the Saudi Vision 2030, Mohammad bin Salman said, "We will do our utmost to ensure that Muslims from around the world can visit the Holy Sites.. This, however, is not currently the case. Qatari citizens, for example, are only being given a 1,200 quota to attend the pilgrimage and was actually banned from entering the country in 2018. Riyadh claims this is an exceptional blockade due to the Hajj, but Travel agents in Qatar stated the opposite. They said that the online registration for Qatari was blocked by Saudi Arabia's ministry for the Hajj (Al Jazeera, 2018). Universal Declaration of Human Rights stated in Article 18 that everyone has the right to manifest his religion or belief in teaching, practice, worship and observance. As in Islam, pilgrimage to the holy city of Mecca is one of the five pillars of Islam which state 
that all adult Muslims, who are physically and financially capable of undertaking the journey, must do so regardless of their nationality.

\section{Press Freedom}

The State has duties to implement this right. Those are their duties to make sure that this fundamental right can be enjoyed without any undue restriction. Saudi, through their NTP (the National Transformation Program), plight to a more transparent government. Unfortunately, it has not been followed by any freedom of speech and press freedom (Kinninmont, 2017).

The assassination of Jamal Khashoggi and arrest of Samar Badawi and Nassima al-Sadah are two examples that the Kingdom has not fully committed to this right. Khashoggi is one of the most prominent Saudi journalists and a consistent critic of the Saudi state. The CIA has voiced its suspicions that Mohammad Bin Salman is responsible for the killings (Bouoiyour, 2018).

The Saudi regime uses Islam and Islamic values as a pretext for their authoritarian rule. It also mentions values such as moderation, tolerance, excellence, discipline, equality, and transparency. This rhetoric, however, is far away from reality. What kind of transparency do they mean? There is strong evidence that Jamal Khashoggi was killed in the Saudi embassy in Turkey. Even though the Kingdom said that they are not involved in the journalist's murder, this case has led to mass withdrawals (including JP Morgan, Ford, Softbank, Uber Technologies, AOL, Siemens, BNP) from the Saudi Future Investment Initiative (FII) Summit and had the most adverse impact on banks and financial services, materials, and technology (Bouoiyour, 2018).

Richard Branson, the Virgin President, resigned from his directorship of two Saudi's tourism projects around the Red Sea and believes the disappearance of Jamal Khashoggi would change the business relationship between the Kingdom and the West (Branson, 2018). Prior to the event, Bouoiyour found that banking and financial services were negatively affected by $-5.09 \%$ after two days and -9.16 $\%$ after 10 days. Materials were adversely influenced by $-2.74 \%$ on the first day of trading, and by about $-8.6 \%$ after 10 days. Software and computer services (i.e., technology) were negatively impacted by $-3.64 \%$ after 5 days and by -4.52 after 10 days. In contrast, the Oil and Gas 
sector responds differently to this event. It reacts positively by 1.49 on the first day of trading, negatively and modestly by $-0.37 \%$ after two days, while it did not record any statistically significant results up to 10 days. Those aspects are also some focus of this Vision. UNCTAD's publication in 2017 showed inward investment into Riyadh dropped markedly (Bouoiyour, 2018). It proved that the serious human right violations can substantially hinder progress in the realisation of the Vision.

\section{Discussion}

To be more correct on an empirical basis, the Saudi Vision 2030 should have added some sentences on the foreword, on the lines of, "We will do our utmost to ensure that Muslims from around the world can visit the Holy Sites, as long as the nation which the Muslim come from does not have a problem with Saudi Arabia." Or the kingdom should follow its own words and allowed all Muslims all over the world to do the pilgrimage, regardless of the political situation.

Repressions towards human rights can only lead to a greater bounce back-resistance against the Kingdom. Even if people have no choice to express their interests, it could give them an intention to build a stronger attempt to send the message, the only political alternative: political violence. A worse and more unstable condition could arise both within Saudi Arabia and regionally, culminate in a business-unfriendly environment.

The stability of the political situation regionally and domestically is essential to ensure a peaceful environment conducive to economic development. Therefore, they need to lower their interference in the other country's internal affairs. Notably, Saudi should stop their support of military action in Yemen and Syrian civil wars that cause to emerge a massive international censure. The Kingdom should also give loosen their suppression to their own people. The forcible suppression only can generate bigger or violent protest. Some nations and companies have shown that they want to do business with Saudi only when there is no human rights violation. Saudi need to bear in mind that. In the domestic issue, thereto, the Kingdom's conservative interpretation of Islam may bring other dissension with the Vision's way. The Vision contains many western notions that contradicted with the view of Saudi's conservative clerics. 


\section{Conclusion}

At the 27th Annual Arab-U.S. Policymakers Conference, titled "What Paths Forward for America in and with the Arab Region?" Mr. Hani Ukayli FTI Consulting Managing Director; former World Bank and Saudi Arabian Atomic and Renewable Regulatory Authority Specialist, said that the Vision is not merely meaningless rhetoric, but a vision and a statement of intent (National Council on U.S.Arab Relations, 2018). Ms. Fatimah Salem A. Baeshen Spokesperson at Embassy of Saudi Arabia in the United States, added that this Vision is aimed at 2030, not for the next one year or two, therefore it should not be judged in the short term. However, even they regard the Vision as a vision, not just rhetoric and the Vision should be assessed in 2030, unless there are changes to the way the regime operates, the statement of intent and the vision is unlikely to be successfully implemented. Lest we forget, 2030 is only 11 years away. Moreover, instrumental reasons are not the only reasons the kingdom should refrain from not human rights violations. The dignity of humans is also a strong moral reason for the protection of fundamental human rights.

\section{References}

Kumaraswamy, P.R., 2007, Revisiting the Yom Kippur War: Introduction, Routledge

Abalkhail, Jouharah M., 2017, Women and Leadership: Challenges and Opportunities in Saudi Higher Education, Vol. 22 No. 2, 165-183

Alshabnan, Ali, 2018, The Politicization of Arab Gulf Media Outlets in the Gulf Crisis: A Content Analysis, Global Media Journal, 16 (30), 1-6

Arabi, Khalafalla Ahmed Mohamed, and Faiz Awad bin Zafrah, 2018, The Impact of Human Capital on Saudi Economic Growth: Emphasis on Female Human Capital, Archives of Business Research, 6 (12), 189203

Baki, Roula, 2004, Gender-Segregated Education in Saudi Arabia: Its Impact on Social Norms and the Saudi Labor Market, Education Policy Analysis Archives, $12(28)$

Baqi S, Albalbeesi A, Iftikhar S, Baig-Ansari N, Alanazi M, Alanazi A, 2017, Perceptions of Gender Equality, Work Environment, Support and Social Issues for Women Doctors at A 
University Hospital in Riyadh, Kingdom of Saudi Arabia.

Bouoiyour, Jamal, Selmi, Refk., 2018, The gruesome murder of Jamal Khashoggi: Saudi Arabia's new economy dream at risk?

Gause, F Gregory, 2016, The Future of U.S.-Saudi Relations: The Kingdom and the Power, Foreign Affairs, 95 (4)

Gause, F Gregory, 2018, Fresh Prince: The Schemes and Dreams of Saudi Arabia's Next King, Foreign Affairs, 97 (3)

Hvidt, Martin, 2018, The New Role of Women in the New Saudi Arabian Economy, Center for Mellemoststudier

Khashan, Hilal, 2017, Saudi Arabia's Flawed "Vision 2030", Middle East Quarterly.

Kinninmont, Jane, 2017, Vision 2030 and Saudi Arabia's Social Contract: Austerity and Transformation, Middle East and North Africa Programme

Klare, Michael T., 2017, From Scarcity to Abundance: The New Geo politics of Energy, Current History

Lim, Merlyna, 2018, Unveiling Saudi Feminism(s): Historicization, Heterogenity, and Corporeality in Women's Movements, Cana- dian Journal of Communication, 43, 461-479

Mitchell, Brendan, and Alfuraih, Abdulrahman, 2018, The Kingdom of Saudi Arabia: Achieving the Aspirations of the National Transformation Program 2020 and Saudi Vision 2030 Through Education, Journal of Education and Development, 2 (3)

Yamada, Makio, 2018, Can Saudi Arabia Move beyond "Production with Rentier Characteristics"? Human Capital Development in the Transitional Oil Economy, Middle East Journal, $72(4)$

Yao, Kuangyi, 2007, Development of Sino-Arab Relations and the Evolution of China's Middle East Policy in the New Era, Journal of Middle Eastern and Islamic Studies (in Asia), 1 (1)

Young, Karen E., 2016, Can the Saudi Economy Be Reformed?, Current History, 355-359.

Kingdom of Saudi Arabia, 2016, $\mathrm{Vi}$ sion 2030.

Kingdom of Saudi Arabia, 2016, $\mathrm{Na-}$ tional Transformation Program 2020.

Al-Jazeera, 5 February 2019, Saudi Arabia, UAE gave US arms to al-Qaeda-linked groups: Report, https://www.aljazeera. 
com/news/2019/02/saudiarabia-uae-gave-weaponsal-qaeda-linked-groupscnn-190205055102300.html

Bayoumi, Moustafa, 2018, US bombs are killing children in Yemen. Does anybody care?, The Guardian, https://www.theguardian.com/commentisfree/2018/ aug/25/us-bombs-yemen-children-humanitarian-disaster

Specia, Megan, 24 June 2019, Saudi Arabia Granted Women the Right to Drive. A Year on, It's Still Complicated, The New York Times, https://www.nytimes.com/2019/06/24/world/ middleeast/saudi-driving-bananniversary.html

National Council on U.S.-Arab Relations, How Best to Understand Saudi Arabia's "Vision 2030" Plan? 2018 Arab-U.S. Policymakers Conference, YouTube
Branson, Richard, 2018, My statement on the Kingdom of Saudi Arabia, virgin.com, https:// www.virgin.com/richard-branson/my-statement-kingdomsaudi-arabia

Human Rights Watch, 2002, Saudi Arabia: Right of Peaceful Assembly Denied, https://www. hrw.org/news/2002/04/04/ saudi-arabia-right-peacefulassembly-denied

The World Bank, 2017, Population, female (\% of total), https://data.worldbank.org/ indicator/SP.POP.TOTL.FE .$Z S ?$ locations $=S A$

The World Bank, 2018, Labor force, female (\% of total labor force), https://data.worldbank. org/indicator/SL.TLF.TOTL. FE.ZS?locations=SA 